\title{
Human resource management, social connectedness and health and wellbeing of older and retired men: The role of Men's Sheds
}

\begin{abstract}
This study analyses human resource management in Men's Sheds in Australia. Men's Sheds are volunteer-based, not-for-profit, grassroots community organisations that provide health related resources and an avenue for largely older and retired men to engage with each other and the community. The research is timely given the escalating numbers of retired men and rising national healthcare costs in Australia. We used a sample of over 200 Men Sheds throughout Australia and matched 419 member responses to 162 leaders. Based on mediation analysis, we found that perceived human resource practices support the retention of membership, and enhance the social connectedness, and health and wellbeing of men members. The quality of relationships between leaders and members was also important for membership retention. The paper demonstrates the importance of human resource management in grassroots community-based organisations and its role in supporting the health and wellbeing of the community.
\end{abstract}

\section{Keywords}

Human resource management, retired men, health and wellbeing, social connectedness, Men's Sheds

\section{Introduction}

Many western countries are experiencing ageing populations with increasing numbers of people leaving the workforce. Of particular concern are the growing challenges regarding men's health and wellbeing post retirement (Golub, Filipowicz, \& Langer, 2002). In June 2010, Australians aged 65 years and older represented $13.5 \%$ of the population and that figure is expected to increase to approximately 23\% by 2041 (Australian Bureau of Statistics, 2011). The health of older men is a critical social issue, particularly given Australia's ageing population (Cavanagh, McNeil, \& Bartram, 2013) and evidence suggests men face significant challenges in making the transition from work to retirement (Warburton \& Lui, 2007) such as a loss of identity and a deterioration in mental and physical health (Butterworth et al., 2006; Marshall, Clarke, \& Ballantyne, 2001; Stryker \& Serpe, 1994). Research has demonstrated that social participation and engaging men within their community to perform meaningful and worthwhile activities is an important vehicle for men to enjoy their retirement, and maintain healthy and active lifestyles into their advancing years (Almedom, 2005; Sirven \& Debrand, 2008, 2012).

The Men's Shed is a volunteer-based, not-for-profit, grassroots community movement which provides opportunities for all men to become involved in various activities in a collegial and supportive environment (Australian Men's Shed Association, 2013). Men's Sheds were first developed in Australia in response to issues regarding the wellbeing of retired men (Golding, 2011). The Sheds bridge the gap between paid work and retirement for older men where they can engage in social activities and perform meaningful tasks such as using machinery, learning how to cook or become involved in community projects (Ballinger, Talbot, \& Verrinder, 2009; Glover \& Brown, 2006; Morgan, Hayes, Williamson, \& Ford, 2007; Ormsby, 2010). This movement is now gaining traction internationally particularly in the UK, Ireland and continental Europe. Mainstream Sheds also provide men with the opportunity to share experiences and express concerns about health and relationships and 
gain access to men's health services (Brown, Golding, \& Foley, 2008; Golding, Brown, Foley, Harvey, \& Gleeson, 2007; Misan, 2008; Morgan, et al., 2007). Despite the growing interest in Men's Sheds, there is little understanding of the role of management practices, (i.e., human resource management (HRM)) and leadership in these organisations and their effect on member outcomes (Cavanagh, et al., 2013).

This paper sets out to examine the process of how Men's Sheds support, through HRM, the social connectedness of men to improve their health and wellbeing. Although systematic management research on Men's Sheds is still in its infancy, previous pilot studies carried out have indicated that the role of shed leaders (known as coordinators) and their approach to the management of the shed, particularly HRM may influence member perceptions of their health and wellbeing (Cavanagh, McNeil, Bartram, \& Leggat, 2012; Southcombe, Cavanagh, \& Bartram, 2013 In press). This paper uses a sample of over 200 Men Sheds throughout Australia (419 member responses matched to 162 leaders (Men's Shed coordinators), and examines the experiences of shed leaders and members concerning the impact of HRM practices, leader member exchange (LMX), the perception of social connectedness, and subsequently perceptions of health and wellbeing and intention to leave.

This paper makes an important contribution to our understanding of Men's Sheds and their significance for health outcomes in a number of ways. First, it is the first large scale representative and systematic study of Men's Sheds in Australia and the world. The paper offers new insights into important strategies that governments and healthcare providers around the world can harness to improve the health and wellbeing of older and retired men. Second, we utilise a multi-level approach (examine both leader and member perception of HR practices) to the study of volunteer based organisations with leader and member matched responses. This methodological approach is rare within the volunteering and HRM literature. Third, this paper provides new insights into the role of management practices, especially HRM and leadership, in supporting social connectedness with a vulnerable group of men in a volunteer-based organisation. Our paper demonstrates the importance of the effective use of HRM practices in an organisational form generally not studied or considered intellectually relevant to many HRM scholars.

The paper is outlined as follows. First, we discuss the Men's Shed movement, the importance of HRM in grass roots community and volunteer organisations, and the role of Men's Sheds in developing social connectedness. Second, we present six hypotheses. Third, we present our methodology and findings. Finally, we present our discussion and conclusions focusing on the importance of HRM in community organisations.

\section{Men's Sheds}

There are two organisations that service the Sheds in Australia. Mensheds Australia (MSA) was established in 2006 (Australian Men's Shed Association, 2013). It is a registered health promotion charity that partners with health and other organisations, such as small businesses and local TAFE's (Training and Further Education institutions, providers of vocational education and training) to support men's groups and Sheds around Australia. The majority of funding is sourced from the private sector and bequests. MSA helps Sheds gain funding for projects and activities to support local communities. The second organisation is the Australian Men's Shed Association (AMSA) which was formally established in 2007 (Mensheds Australia, 2013). AMSA is a member based organisation founded on the principle 
of sharing information between Sheds. Services are provided freely to registered and nonregistered Sheds, and membership is free for all services.

An important part of engaging men in their communities is the development of meaningful and strong relationships with other men. Men's Sheds do this through providing a safe place for education, training and recreation (Arney \& Westby, 2012) whereby social and informal learning can occur (Brown, et al., 2008; Golding, 2011; Golding, et al., 2007; Golding, Kimberley, Foley, \& Brown, 2008). The Sheds are a place where men can interact, volunteer and share ideas about common interests, learn how to deal with their problems, restore selfesteem and self-respect and connect with their traditions and culture (Misan, 2008). Singh and Misra (2009) contend that community participation and enhancing family ties and cultural connections are vital to reduce feelings of loneliness and other psychological health issues often experienced by older people.

\section{HRM and Leadership Practices in the Sheds}

There has been growth of interest in HRM in both healthcare and volunteer organisations in recent years (Bonias, Bartram, Leggat, \& Stanton, 2010; Stanton, Young, Bartram, \& Leggat, 2010). The systematic and formalized management of people within organisations is critical to the effective and purposeful use of human effort irrespective of the organisation or its form (e.g., private-for-profit, not-for-profit, non-government organisations). HRM comprises an integrated set of HR functions (including human resource development, job design and analysis, performance management, occupational health and safety, remuneration and human resource planning) designed to enhance individual and ultimately organisational performance (Kramar, Bartram, \& DeCieri, 2014). Little is known about the practice and effects of HRM in Men's Sheds.

Recent research on HRM in Men's Sheds by Cavanagh, McNeil and Bartram (2013) employed a qualitative approach and conducted focus groups with a total of 34 male participants in two Men's Sheds. The study found that men's participation in Men's Shed activities including health checks and health promotion was primarily driven by quality relationships between the Shed coordinator and members, with the men themselves and HR practices such as training and development, human resource planning and occupational health and safety. Formalised HR practices enabled the men to participate safely and productively in Men's Shed activities, particularly carpentry and metal work.

HRM literature has demonstrated that effective HR practices that are congruent with organisational goals can have positive effects on individual wellbeing, as well as individual and organisational performance (Bartram \& Casimir, 2007; Boxall, Ang, \& Bartram, 2011; Schuler \& Jackson, 1987; Stanton, et al., 2010). The logic is that HRM systems influence and align employees' attitudes and behaviours with the strategic goals of the organisation and thereby increase employee commitment, empowerment and individual performance (Bonias, et al., 2010; Schuler \& Jackson, 1987). Distinct from paid workers who are subject to formal HR policies and practices, this research seeks to establish the extent to which the HR practices of the Sheds impact on the attitudes and behaviours of members. In the context of considering health outcomes for older adults, the lack of research on this area signals a significant absence. In particular, this absence has the potential to limit the capacity of the Sheds to achieve their stated objectives of contributing to the wellbeing for older adults. What is required is further research within this context that enables us to consider the relationships between forms of HR practice and important outcomes for the men such as 
social connectedness. We propose that positively perceived HR practices within organisational contexts will be related to enhanced forms of social connectedness and LMX, resulting in positive Shed member wellbeing. LMX is a relationship-based approach to leadership (Graen \& Uhl-Bien, 1995). At the heart of the LMX theory is the notion that effective leadership processes occur when leaders and followers are able to develop mature partnerships and enjoy the benefits these relationships entail (Graen \& Uhl-Bien, 1995).

\section{Social Connectedness}

Social connectedness is critical to the development of meaningful and strong relationships, and enhancing health and wellbeing (Chavis \& Wandersman, 1990; Lee, Keough, \& Sexton, 2002; Lee \& Robbins, 2000; Pretty, Conroy, Dugay, Fowler, \& Williams, 1996). Social connectedness is used to describe an aspect of the self that reflects subjective awareness of interpersonal closeness. This sense of closeness is a critical component of one's sense of belonging and is based on the aggregate experiences of proximal and distal relationships. In this respect, social connectedness is an enduring and ubiquitous experience of the self in relation with the world (Lee \& Robbins, 2000). Townsend and McWhirter (2005) contend that the definition of 'connectedness' varies from article to article and that it is an intricate and multi-dimensional construct. Common terms used to describe connectedness include dependence, embeddedness, engagement and belongingness. The conceptualisation of connectedness is also varied in the literature, with connectedness meanings either relating to self; or relating to others such as family, friends, colleagues and social groups (Whitlock, 2007).

Social connectedness provides a personal sense of identity, as well as a sense of place in society and is a key feature in identity development and in emotional wellbeing (Townsend \& McWhirter, 2005). For older people who may be confronting risks of social isolation, forms of social connectedness become critical. As Cornwell, Laumann and Schumm (2008) et al suggest, 'social roles and activities are central to treatments of successful ageing' (p. 186), further remarking that the social networks that constitute social connectedness 'are essential to successful ageing because they provide embeddedness in systems of norms, control and trust; access to information and other resources; and social support' (p. 186). Further to this, Cornwell and Laumann (2013) support the need to be aware of changes in forms of social connectedness. In their work, they recognize that 'life-course transitions like retirement, widowhood and residential changes can drastically alter a person's network' (p. 1). This suggests the need not only to consider forms of social connectedness that may be lost, but also to consider newly created forms of social connectedness that develop at the point of transition. Taken together, the research on social connectedness suggests that it has important consequences for health outcomes, but also that it is an area that requires further research.

\section{Hypotheses Development}

We found no research on the effect of HRM on social connectedness. However, social psychology research has demonstrated that HRM practices are associated with social cohesion and feelings of belongingness to groups (Bartram, Karimi, Leggat, \& Stanton, 2014; Forrester \& Tashchian, 2006). Much of the literature investigates the relationships between leadership and the self-concept and/or social identity of followers (Thomas, Martin, \& Riggio, 2013; Zhu, Sosik, Riggio, \& Yang, 2012). Bartram et al, (2014) argue that HRM practices are associated with stronger feelings of intra-group identification and feelings of 
social closeness among health care workers. HRM research has established that congruent HRM practices have the intended purpose of creating a sense of community and a sense of closeness or 'team spirit' among organisational members. Through infusing organisational participants with a sense of community and commitment to the organisation and particular sub-units within the organisation, HRM practices may facilitate the development of stronger social bonds within organisations (Bartram, et al., 2014). For example, training and development, particularly at the team level, may enhance communication, cohesion and coordination of activities and further enable group members to develop a shared understanding of tasks (Postmes, 2003). Involvement in decision making can foster familiarity of members and promote social cohesion (Pfefer, 1998), with factors such as group prestige, distinctiveness and salience, and formation factors (Gundlach, Zivnuska, \& Stoner, 2006). Members who identify with the group become more involved in the group and consequently create a social world around the group and inter-personal closeness.

HRM practices can enhance feelings of social connectedness among organisational participants. Organisations are multi-level entities and there is a need to appreciate how HR systems are understood, communicated and transmitted between front-line leaders and their subordinates (Bowen \& Ostroff, 2004; Stanton, et al., 2010). The HRM performance chain is predicated on managerial application of HRM policies and practices and the interpretation of those policies by subordinates (Bowen \& Ostroff, 2004; Boxall \& Macky, 2007). For HR practices to positively affect subordinate attitudes and behavior (e.g., social connectedness) they have to be interpreted by subordinates as intended by management - that is in a clear, consistent and responsive way (Bowen \& Ostroff, 2004). In the case of the Men's Shed, the HR practices are intended by the Shed Coordinator and its Board to develop a safe and inclusive environment that facilitates social connectedness. We propose the following hypothesis.

H1: The relationship between leader HR practices and members' social connectedness is mediated by members' perceived HR practices.

The quality of the leader and subordinate relationship may have an important impact upon the way in which leader HR practices are interpreted by follower HR practices. Purcell and Hutchinson (2007) argue that LMX is central to effective people management through its role in facilitating positive inter-personal relationships. We argue that between-group agreement regarding the HR practices by front-line management and their subordinates are also critical to effective management (Stanton, et al., 2010). High quality leader-member relationships enable management practices to engender socio-emotional benefits and engender 'feelings of obligations, gratitude, and trust' among subordinates (Blau, 1964, p. 93). In situations where a high quality relationship exists between the leader and the subordinate, the subordinate may positively interpret intended HR practices as supporting and enhancing their ability to perform their organisational role. More precisely, when supervisors (leaders) show their subordinates 'consideration, respect and support through their communication exchanges, higher-quality LMX relationships result in a higher self-concept' (Jacques, Garger, Thomas, \& Vracheva, 2012, p. 4). This process is underpinned by the creation of trust, respect and mutual obligation, as well as stimulating mutual learning and accommodation through interactive communication, and leader and member value agreement (Graen \& Uhl-Bien, 1995). 
We argue that LMX is likely to mediate the relationship between espoused HRM practices as interpreted by Shed coordinators and those HRM practices experienced by Shed members. Effective HRM practices developed and implemented by the Shed coordinators are likely to facilitate positive exchanges between them and their members (e.g., providing a safe work environment, training activities within the Shed and recruitment drives). Quality relationships with the leader may act as a conduit to enhance favourable perceptions of members' experience of HRM. This is supported by the work of Li, Sanders and Frenkel (2012, p. 1060) who argue that 'the HRM system is an important organisational influence that communicates the organisation's values, goals and procedures to both managers and employees'. We propose the following hypothesis:

H2: The relationship between leader HR practices and leader-member exchange is mediated by members' perceived HR practices.

Labonte and Reid (1997) define wellbeing as the physical, emotional and social health of an individual which is determined by an individual's abilities and their level of connectedness with others. Ballinger (2009) contends that social connectedness and having a sense of meaning and purpose contribute to an individual's sense of wellbeing. Social connectedness provides a personal sense of identity, as well as a sense of place in society and is a key feature in identity development and in emotional wellbeing (Townsend \& McWhirter, 2005). Baumeister and Leary (1995) and Cavanagh, McNeil and Bartram (2013) found inextricable links between social connectedness, a sense of belonging, and meaning within large social and community groups and the wellbeing of individuals. Furthermore, social connectedness has also been found to have significant relationships with adult's participation in community activities and psychological and physical wellbeing outcomes (Chavis \& Wandersman, 1990; Lee, et al., 2002; Lee \& Robbins, 2000; Pretty, et al., 1996).

Van De Voorde, Paauwe and Van Veldhoven's (2011) review of 36 quantitative studies from 1995-2010 found that HRM had a positive effect on employee wellbeing in almost $70 \%$ of the 54 data points. However, relatively few studies have included a health-related wellbeing component, resulting in only eight data points for this review. Three data points supported a negative association between HRM and health-related wellbeing, causing conflicting outcomes on the relationship between HR practices and health and wellbeing. Alfes, Shantz and Truss's (2012) study of 613 employees from service organisations in the UK found that employees who perceive HRM practices positively experience higher levels of wellbeing. However, the authors suggest that due to the conflicting results of past studies further research is needed to clarify this relationship. We suggest the following hypothesis:

H3: The relationship between members' perceived HR practices and member's health and wellbeing is mediated by members' social connectedness.

Guest (2002) argues that certain HRM practices (e.g., challenging and interesting jobs) are associated with increased wellbeing of workers such as increased job and life satisfaction. Guest (2002, p. 354) argues for a model of HRM that is 'worker-centred'. Grant, Christianson and Price (2007) examine the relationship between HRM and employee wellbeing. They argue that the relationship is complex and fraught with a number of contradictions. However, it is clear that wellbeing as conceptualized by physical, psychological and social wellbeing can be enhanced through HRM practices. For example, safety practices can increase wellbeing through decreasing accident, injury and illness. Team building can positively 
impact social wellbeing through strengthening interpersonal relationships and social cohesion.

Rousseau, Aube, Chiocchio, Boudrias and Morin (2008) report a positive association between LMX and subjective wellbeing. Nelson, Basu, and Purdie (1998, p. 105) ()()()suggest that social exchanges represent "mutually influencing transactions leading to the development of social relationships over time". There is considerable literature suggesting that the quality of LMX may affect psychological health (Rousseau, et al., 2008). Nelson et al. (1998) suggests leaders that provide 'psychologically secure environments, the infrastructure necessary for accomplishing tasks, and the latitude to make decisions, followers are likely to perceive situations as being governable and non-threatening. Conversely, failure to provide such environments are more likely to result in feelings of isolation, solitude, and lack of control' (p. 106). As discussed above, effective HRM practices are associated positively with favourable health and wellbeing outcomes for organisational participants (Van De Voorde, et al., 2011). We propose the following hypothesis:

H4: The relationship between members' perceived HR practices and member's health and wellbeing is mediated by leader-member exchange.

The relationship between HR practices and employees' intention to leave the organisation has attracted significant attention from researchers and human resource practitioners (Lam, Chen, \& Takeuchi, 2009). According to Kuvaas (2008) and Kuvaas and Dysvik (2010) positive perceptions of HRM practices are negatively associated with intention to leave the organisation. Moreover, Alfes, Shantz, Truss and Soane's (2013) research on 297 service employees in the UK found that perceived HRM practices was linked to employee turnover intentions. This research used perceived organisational support and leader-member exchange within the social exchange theory and suggested that if organisations were able to cultivate a climate of reciprocity they will be likely to elicit positive attitudinal and behavioural outcomes from employees, including remaining with the organisation. We argue that individuals that perceive a sense of social connectedness are likely to develop strong social bonds within their group and hence less likely to leave that group (Bartram, et al., 2014). Given that HR practices are likely to impact social connectedness (see aforementioned discussion on the relationship between HR practices and social connectedness), we propose that social connectedness is likely to mediate the relationship between perceived HR practices and members intention to leave. We propose the following hypothesis:

H5: The relationship between members' perceived HR practices and members' intention to leave a shed is mediated by members' social connectedness.

There is a large body of research that asserts that effective HRM practices including recruitment and selection, training and OHS are negatively associated with employee' intention to leave the organisation (Lam, et al., 2009). In situations of a low LMX, subordinates may perceive HR practices in a negative light and with some suspicion, that is, they are not relevant, nor distinctive and possibly unfair which in turn may lead to intentions to leave the organisation (Stanton, et al., 2010). There has been significant research to indicate that poor quality of working relationships between a leader and subordinate are associated with intention to leave the organisation (Masterson, Lewis, Goldman, \& Taylor, 2000). We propose the following hypothesis: 
H6: The relationship between members' perceived HR practices and members' intention to leave shed is mediated by leader-member exchange.

\section{Data and Methodology}

Data

This paper is grounded in an original data set, collected by the researchers, and based on their capacity to access the Sheds as a result of building strong relations with the organisational leadership of the Sheds. We employed a cross-sectional research methodology, involving a survey of the leaders and members of Australian Mens Sheds affiliated with the Australian Men's Shed Association (AMSA) in July 2012. AMSA provided their database of all Sheds affiliated with the Association, which constituted the sampling frame for this study. This amounted to 749 Sheds in total. A survey pack was sent to every Shed in the sampling frame. The survey pack consisted of three separate questionnaires for three different groups associated with Sheds: (1) a questionnaire for the Leader of the Shed, comprising questions relating to: the current operations of the Shed; current management practices of the Shed; information about the membership of the Shed; levels of participation in the Shed; health care services accessed by members through the Shed; current challenges, achievements and future directions of the Sheds; and the type and quality of assistance provided to the Shed by AMSA; (2) a questionnaire was randomly distributed to five Shed Members, which included questions concerning their experience of the Shed, the perceived outcomes of their participation in the Shed, and their access to health services; and (3) a questionnaire for a Health Care Worker who provides support to each Shed, which included questions about the services offered to members through their local Sheds, the key health challenges facing Shed Members, and the ways in which access to health services could be improved through member's interaction with their Shed. Approximately 3,355 member questionnaires, 749 leader and Health Care Worker questionnaires were distributed.

A total of 498 member and -173 leader useable questionnaires were returned. The matchedpair requirement and list-wise deletion of cases with missing data resulted in a final sample of 419 member responses, matching to 162 leaders. This represents a Shed response rate of 21 percent, a level generally regarded as acceptable in social science research (Alreck \& Settle, 1995). An important consideration in this study is that some of the HR practices that are put in place are not translated in practice and hence are not experienced by the members. Therefore, it is possible that members' experience of these HR practices may in fact differ from what the leaders believe actually happened. The differences are likely to result in different expectations from both parties, leading to outcomes that may not be expected. This also points to the need to consider the organisational location of respondents when analyzing their responses, as this location is an important element in seeking to explain perceptions and understandings of individuals.

\section{Variables}

\section{Independent Variable: Leader and Members’ Perceived HR Practices}

Items on HR practices were largely adapted from established scales or existing measures of HR systems. The initial set includes 19 items: 5 items in Recruitment (e.g. this Shed promotes their Shed to the local community) and 6 items in Training and Development (e.g. This Shed is committed to the training and development of its members) were adopted from Zacharatos, 
Barling and Iverson (2005). Eight items in Health and Safety Climate were taken from Edgar and Geare (2005).

Exploratory factor analysis suggests that 15 of the 19 HR items are internally consistent across both leader and member groups, with 4 items in Recruitment, 5 items in Health and Safety Climate and 6 items in Training and Development. A five-point Likert scale where $1=$ strongly disagree, $2=$ disagree, $3=$ neither agree nor disagree, $4=$ agree and $5=$ strongly agree was used. The factor analyses show that the Recruitment items load into a single factor with $\alpha$ values of 0.732 for member and 0.637 for leader. The Health and Safety Climate items have $\alpha$ values of 0.818 and 0.778 for member and leader respectively. Finally, the $\alpha$ value for member in Training and Development is 0.926 while that for leader is 0.893 . Consistent with the approach by Liao, Toya, Lepak and Hong (2006), these three factors are then aggregated and averaged to form both leader and member HR practices. A summary of this and individual item scores is presented in Table 1.

Insert Table 1 about here

\section{Outcome Variables}

Health and Wellbeing

We adapted an old version of the SF-8 Health Survey which is applicable to elderly respondents. As the type of questions vary from using Likert scale measurements and yes and no responses, we created two set of items. The first set Health and Wellbeing 1 consists of 6 items such as 'during the past 4 weeks, how much did pain interfere with your normal daily activities?' and 'has your health limited your social activities, such as visiting friends or close relatives?' These items load onto one factor that has a $\alpha$ value of 0.789 . The second set Health and Wellbeing 2 consists of 4 items such as 'during the past 4 weeks, have you had any of the following problems with your regular daily activities as a result of your physical health? (a) accomplished less than you would like?; (b) were limited in the kind of work or other activities?' One factor represents these 4 items with a $\alpha$ value of 0.819 .

\section{Intention to Leave Shed}

Following the thinking around Mobley, Horner and Hollingsworth (1978), we used two items to measure the intention of members to leave the Shed, i.e. 'how often do you think about leaving this Shed"' and 'how likely is it that you would actually leave this Shed within the next year?' Reliability analysis shows a $\alpha$ value of 0.675 .

\section{Mediating Variables}

Members' Social Connectedness

We used Lee, Draper and Lee's (2001) items to measure members' social connectedness. The measurement consists of 20 items, 10 of which are negatively worded. These items are measured using a Likert-5 scale. These are then averaged to give the means score of social connectedness.

\section{Leader-member Exchange}

Our measurement of leader-member exchange was derived from Graen and Uhl-Bien (1995). This is based on a set of 7 items including 'do you know where you stand with your Shed leader, and do you usually know how satisfied the leader is with what you do?' and 'how well 
does the leader understand your problems and needs?' and using a Likert-5 scale. The 7 items load onto one factor with a $\alpha$ value of 0.880 .

A summary of the attributes of these key variables is presented in Table 2.

Insert Table 2 about here

\section{Control Variables}

We included seven control variables. Our questionnaire asked for the year of birth of the respondents and we take the difference of their year of birth and the year 2012 to derive their age. The average age of our respondents are 69 years old. We also asked the respondents if they attend other sheds (coded yes $=1$ and no $=0$ ). Only 10 percent of respondents attend other sheds. Respondents were asked the question 'in the last 12 months, how many training programs have you undertaken through your involvement with the Shed?' The average response is 1.09, therefore about an average of one training program per respondent. We also asked the question 'in the last 12 months, how many health services have you accessed through the Shed?' The average response is 0.75 . In addition to the 4 control variables that are collected from members, we also included another 3 control variables with information collected from the leaders. The first variable is how long is the Shed open for members in an average week. The second variable is how many times does health care worker visit the Shed per year, while the third variable is how many members there are in the Shed.

The correlations of the all variables used in this study are shown in Table 3.

Insert Table 3 about here

\section{Results}

As seen from the conceptual framework, we are interested in testing the full mediation effect for Hypothesis 1 (Leader HR Practices $\rightarrow$ Member Perceived HR Practices $\rightarrow$ Member Social Connectedness) and Hypothesis 2 (Leader HR Practices $\rightarrow$ Member Perceived HR Practices $\rightarrow$ Leader-member Exchange). We further propose that multiple mediators are involved in member perceived HR practices relationships with health wellbeing and intention to leave shed. These mediators are member social connectedness and leader-member exchange. We test the mediation following Baron and Kenny (1986). We also use nested models in our testing of the hypotheses, as there are multiple members per shed represented in our dataset.

Table 4 shows the results of the testing of Hypotheses 1 and 2. Model 1 shows the regression model that involves only the control variables and their effects on members' perceived HR practices. Model 2 adds the leader HR practices variable. Leader HR practices is found to have a positive significant effect on members' perceived HR practices ( $b=0.15, p<0.01)$. The $\Delta \mathrm{R}^{2}$ of 0.019 is also found to be highly significant $(F=8.83, p<0.01)$, demonstrating the added explanatory power by adding leader HR practices into the model.

Insert Table 4 about here 
Models 3 and 4 in Table 4 present the results of testing of Hypothesis 1. Model 3 shows the regression effects of members' perceived HR practices on their social connectedness. The coefficient in this case is insignificant $(b=-0.01, p>0.10)$. While the mediation tests emphasize the need for significant relationships among all the variables in a mediation, in this case leader HR practices, member perceived HR practices and member social connectedness, some researchers have asked that the condition for the relationship between the ultimate independent variable and the outcome variable be relaxed (Hayes, 2009; McKinnon, Krull, \& Lockwood, 2000; Shrout \& Bolger, 2002). The reason for this is that confounding, suppression and interactive effects could attenuate the independent-dependent variables relationship, in our case the relationship between leader HR practices and member social connectedness.

Model 4 presents the regression model to test the mediation effect. In order to observe the mediation effect, a reduction in significance and effect of leader HR practices on member social connectedness after the inclusion of member perceived HR practices should be observed. We used the Sobel test to observe this. The Sobel test was initially suggested by Baron and Kenny (1986) and has subsequently become commonly adopted in mediation testing in management research (Wood, Goodman, Beckmann, \& Cook, 2008). In Model 4, the effect of member perceived HR practices on member social connectedness is found to be positive significant $(b=0.08, p<0.001)$. The inclusion of member perceived HR practices improves the explanatory power of the model significantly $(F=50.29, p<0.01)$. At the same time, leader HR practices' effect has become more negative $(b=-0.02, p<0.10)$. The Sobel test result is significant $(Z=2.75, p<0.01)$, suggesting that the relationship between leader HR practices and members' social connectedness is strongly mediated by members' perceived HR practices. Hence, Hypothesis 1 is supported.

Models 5 and 6 in Table 4 show the regression results of Hypothesis 2 testing. In Model 5, it is evident that the direct effect of leader HR practices on leader-member exchange is insignificant $(b=0.03, p>0.10)$. This is consistent with the case when the dependent variable is member social connectedness. In Model 6, member perceived HR practices is shown to have a positive significant effect on leader-member exchange $(b=0.22, p<0.001 ; F=171.85$, $p<0.001)$. The Sobel test result is also significant $(Z=2.91, p<0.01)$, suggesting that the relationship between leader HR practices and leader-member exchange is strongly mediated by members' perceived HR practices. Hypothesis 2 is also supported.

The tests of $\mathrm{H} 3$ and $\mathrm{H} 4$ suggest that the relationship between members' perceived HR practices and health wellbeing involves two mediators, namely member social connectedness and leader-member exchange. Likewise, the same two mediators are proposed in the relationship between members' perceived HR practices and intention to leave shed (H5 and H6). Preacher and Hayes (2008) show the procedure on how this can be analyzed. We use seemingly unrelated regression analysis to analyze these multiple mediation models as it allows us to derive the individual and collective mediation effects.

As we have two measurements for health wellbeing, these are being tested in separate models, i.e. Models 1 and 2 in Table 5. The results presented in these two models show identical results. Members' social connectedness is shown to have a positive effect on health wellbeing in both cases ( $b=0.82, p<0.001$ for Health Wellbeing 1 and $b=0.66, p<0.001$ for Health Wellbeing 2). The results of seemingly unrelated regression also show that the mediation via members' social connectedness is highly significant in both cases $(Z=5.82$, 
$p<0.001$ for Health Wellbeing 1 and $Z=5.22, p<0.001$ for Health Wellbeing 2). This provided support for Hypothesis 3. On the other hand, leader-member exchange has been found to be insignificant in both instances ( $b=-0.01, p>0.10$ for Health Wellbeing 1 and $b=-0.03, p>0.10$ for Health Wellbeing 2). The mediation effects are also insignificant $(Z=-0.10, p>0.10$ for Health Wellbeing 1 and $Z=-0.56, p>0.10$ for Health Wellbeing 2). Hypothesis 4 is thus not supported.

Insert Table 5 about here

Model 3 in Table 5 presents the results for Hypotheses 5 and 6. Members' social connectedness is found to have a significant negative effect on intention to leave shed $(b=-$ $0.30, p<0.001)$. The seemingly unrelated regression analysis also suggests a negative significant mediation effect $(Z=-3.19, p<0.001)$. Hypothesis 5 is thus supported. In addition, leader-member exchange is shown to have a negative significant effect on intention to leave shed $(b=-0.25, p<0.001)$. The mediation is also highly significant $(Z=-4.28, p<0.001)$. Therefore, Hypothesis 6 is also supported.

\section{Discussion and Conclusion}

Men's Sheds provide a conducive environment through HRM whereby men members can seize opportunities to build relationships and enhance their health and wellbeing. Member perceptions of HR are crucial to the development of member attitudes and outcomes (Bowen \& Ostroff, 2004; Gould-Williams, 2007). However, it is important to note that social connectedness and LMX strengthen the relationship between HRM practices and member health and wellbeing. The findings demonstrate the important role of both HR practices and the quality of leader member relationships to the development of member perceptions of social connectedness and health and wellbeing. Among these important HR practices are various forms of recruitment, health and safety, and training and development. Moreover, member perceptions of HR practices are also crucial to their decisions regarding the intention to leave the organisation. This relationship is strengthened by the quality of the relationship between the Shed coordinator and the members. It is also clear that positive member perceptions of HR strengthens the relationship between management espoused HR practices, social connectedness and LMX. We now discuss these key findings, which combine to illustrate the value of the relationships proposed in the conceptual framework (Figure 1).

First, this study enhances our understanding of the chain of effects involving HRM and leadership in voluntary and community organisations such as Men's Sheds and the quality of coordinators and members relationships impacting on men's wellbeing. The process is heavily dependent upon social connectedness and how Shed leaders enable it in the Sheds. Social connectedness is critical to the development of meaningful and strong relationships, and enhancing health and wellbeing (Lee, et al., 2002; Lee \& Robbins, 2000). This is particularly important in Men's Sheds, which are a place where men can interact and share ideas about common interests, learn how to deal with their problems, restore self-esteem and self-respect (Misan, 2008). It is through HRM and effective leadership that we can encourage men to remain in the Shed. The effects of social connectedness and health and wellbeing we argue are contingent on men remaining in the Shed. The pivotal role of social connectedness and its effect on intention to leave and health and wellbeing are important results which coincide with Townsend and McWhirter (2005) and Lee and Robbin's (2000) research. To 
develop social connectedness organisations need effective management and leadership at the Shed.

Second, our findings are important because most HR researchers do not study HRM in volunteer grass-roots community organisations. There is an assumption by HR and management scholars that these organisations do not use HRM or it is not relevant. These results clearly indicate that HR and building effective leader and member relationships is critical to Men's Sheds supporting the health and wellbeing of men. This study shows that HR and effective leadership is valuable, not only for large private businesses but also for small to medium sized grassroots community organisations. Hutchinson (2007) and Graen and Uhl-Bien (1995) suggest that positive behaviour outcomes result when effective partnerships are developed between leaders and followers. Cavanagh, McNeil and Bartram (2012) found that health promotion and wellbeing was enhanced through the quality of relationships between coordinators and men members. HR practices such as training, OHS and recruitment affect men's health and wellbeing through fostering their feelings of social connectedness within the Shed.

Third, social connectedness is pivotal to enhancing self-report health and wellbeing. For HR practices to create positive member attitudes and behaviours, the practices developed need to support social connectedness. HRM practices such as recruitment, OH\&S and training seem to improve member perceptions of social connectedness (Pfefer, 1998; Postmes, 2003). This finding corresponds with Bartram et al (2014) and Forrester and Tashchian's (2006) research where HRM practices are associated with social cohesion and feelings of belongingness to groups. Furthermore, practices such as training and development are particularly useful in enhancing cohesion and connectedness among members (Postmes, 2003).

Fourth, our findings demonstrate the importance of LMX in strengthening the relationship between perceptions of HR and reducing intention to leave. This finding was also supported by Alfes et al, (2013), Stanton et al, (2010) and Masterson et al, (2000) where the quality of the relationship between leaders and members was strongly associated with intention to stay with the organisation. The quality of leader-member relationships is central to the success of the Sheds. Moreover, espoused management HR practices and how they are perceived by members is crucial to building quality relationships between the Shed leader and the members. Correspondingly, Jacques et al (2012) suggests that when a higher quality relationship exists between the leader and the member then this will have a positive impact on the perception of HR practices.

Our results have important implications for peak Men's Sheds bodies, Men's Shed Coordinators and government policy makers. The results show the importance of systematic and effective HR practices and leadership within the Men's Sheds. We recommend that both AMSA and the MSA continue to invest in the development of management and leader guidelines. These guidelines can be used to inform Men's Shed Coordinators, many of whom may not have previous management experience to develop formalised HR practices that can support the Sheds, goals and vision. The implications of our findings for Coordinators demonstrate the importance of HR practices in supporting the sustainable and effective operation of the Men's Sheds and positive outcomes for men members. Government policy makers should be aware that Men's Sheds provide a cheap and innovative way to deliver primary social and basic healthcare to vulnerable groups of men within our community. 
These results illustrate that Men's Sheds are making a difference, albeit based on the perceptions of men members we sampled.

This study is not without limitations. First, the results of this study may be subject to common method bias. Collecting data using a single or common method, such as a selfadministered questionnaire, may introduce a systematic response bias that may affect the validity and reliability of the results. To reduce this problem we had both managers and members complete separate questionnaires outlining the HRM practices used in the Sheds. Second, our health and wellbeing measure is self-report. We would argue that members are in the best position to rate their own health and wellbeing. Nevertheless, we would encourage future research that encapsulates more independent measures of health and wellbeing of men members.

In conclusion, this study has demonstrated the importance of HRM within a non-business setting. Grass-roots and community organisations comprising largely of a volunteer membership are important contexts within which HRM has a valuable role. The study reported that perceived HR practices support the retention of members, and enhance the social connectedness, and health and wellbeing of men members. The quality of relationships between leaders and members was also important for membership retention. This research confirms that HR policies and practices are critical for volunteer community-based organisations dealing with escalating social welfare challenges such as an ageing population and growing number of retirees. 
Figure 1. Conceptual framework of $\mathrm{HR}$ practices and their impact

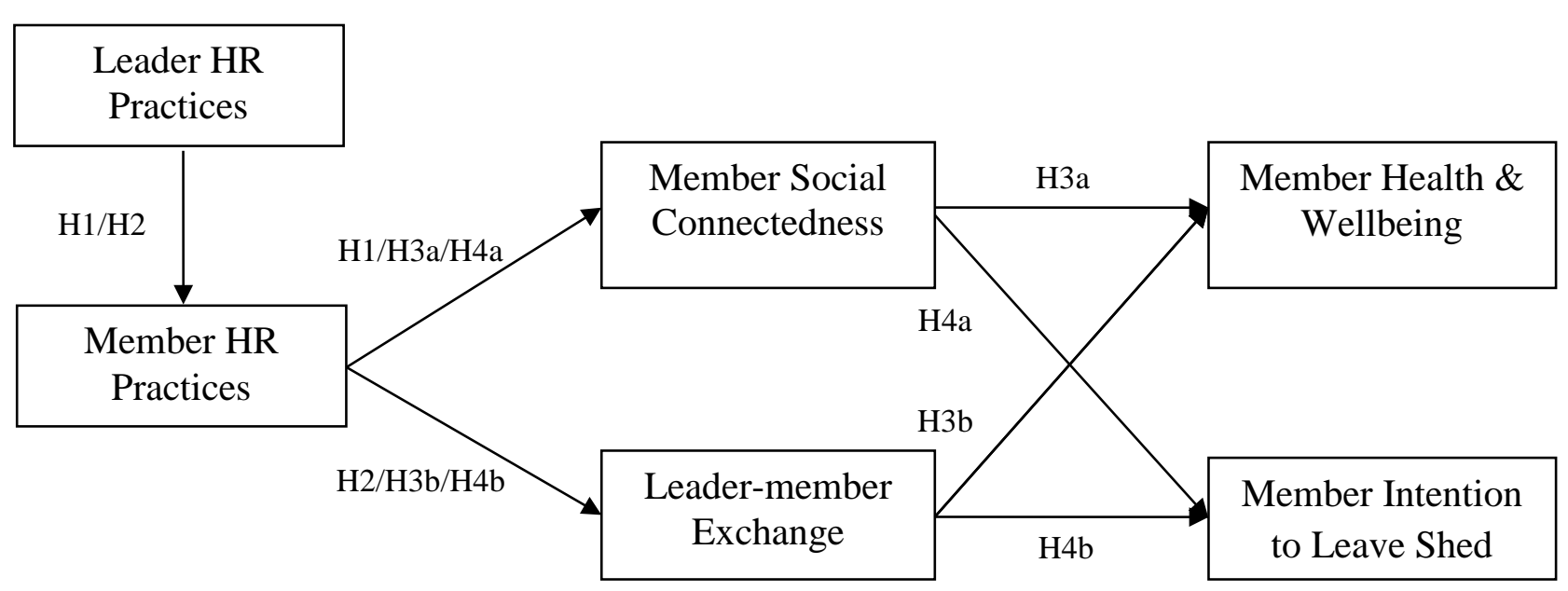


Table 1. HR Practices

\begin{tabular}{|c|c|c|c|}
\hline Variable & Items & Member & Leader \\
\hline \multirow[t]{8}{*}{ Recruitment } & $\begin{array}{l}\text { This Shed has formalized recruitment policies and } \\
\text { practices }\end{array}$ & $\begin{array}{c}3.68 \\
(1.01)\end{array}$ & $\begin{array}{c}3.68 \\
(1.11)\end{array}$ \\
\hline & This Shed has an induction pack for new members & 3.58 & 3.65 \\
\hline & & $(1.10)$ & $(1.19)$ \\
\hline & This Shed promotes their Shed to the local & 4.27 & 4.24 \\
\hline & community & $(0.73)$ & $(0.87)$ \\
\hline & This Shed uses open days and fundraises to recruit & 3.73 & 3.83 \\
\hline & new members & $(1.02)$ & $(1.01)$ \\
\hline & Cronbach Alpha & 0.732 & 0.637 \\
\hline \multirow{11}{*}{$\begin{array}{l}\text { Health and } \\
\text { Safety }\end{array}$} & The Shed's working conditions are good & 4.22 & 4.11 \\
\hline & & $(0.76)$ & $(0.92)$ \\
\hline & The health of the members has not suffered as a & 4.42 & 4.43 \\
\hline & result of working in this Shed & $(0.59)$ & $(0.81)$ \\
\hline & The members always report feeling safe working in & 4.10 & 4.05 \\
\hline & this Shed in these conditions & $(0.72)$ & $(0.85)$ \\
\hline & This Shed does what it can to ensure the wellbeing of & 4.45 & 4.50 \\
\hline & its members & $(0.59)$ & $(0.58)$ \\
\hline & This Shed spends enough resources on health and & 3.94 & 3.87 \\
\hline & safety-related matters & $(0.87)$ & $(0.94)$ \\
\hline & Cronbach Alpha & 0.818 & 0.778 \\
\hline \multirow{11}{*}{$\begin{array}{l}\text { Training and } \\
\text { Development }\end{array}$} & This Shed has formalised training and development & 3.53 & 3.53 \\
\hline & policies and practices & $(1.05)$ & $(1.09)$ \\
\hline & Providing members with training beyond that & 3.45 & 3.47 \\
\hline & $\begin{array}{l}\text { mandated by government regulations is a priority in } \\
\text { this Shed }\end{array}$ & $(0.98)$ & $(1.11)$ \\
\hline & The coordinator/leader encourages members to & 4.00 & 4.14 \\
\hline & extend their abilities & $(0.87)$ & $(0.66)$ \\
\hline & This Shed provides members with training & 3.87 & 4.04 \\
\hline & $\begin{array}{l}\text { opportunities enabling them to extend their range of } \\
\text { skills and abilities }\end{array}$ & $(0.92)$ & $(0.81)$ \\
\hline & $\begin{array}{l}\text { Members get the opportunity to discuss their training } \\
\text { and development requirements with the coordinator/ } \\
\text { leader }\end{array}$ & $\begin{array}{c}3.82 \\
(0.98)\end{array}$ & $\begin{array}{c}3.99 \\
(0.89)\end{array}$ \\
\hline & $\begin{array}{l}\text { This Shed is committed to the training and } \\
\text { development of its members }\end{array}$ & $\begin{array}{c}3.87 \\
(0.94)\end{array}$ & $\begin{array}{c}4.03 \\
(0.90)\end{array}$ \\
\hline & Cronbach Alpha & 0.926 & 0.893 \\
\hline
\end{tabular}


Table 2. Outcome and Mediating Variables

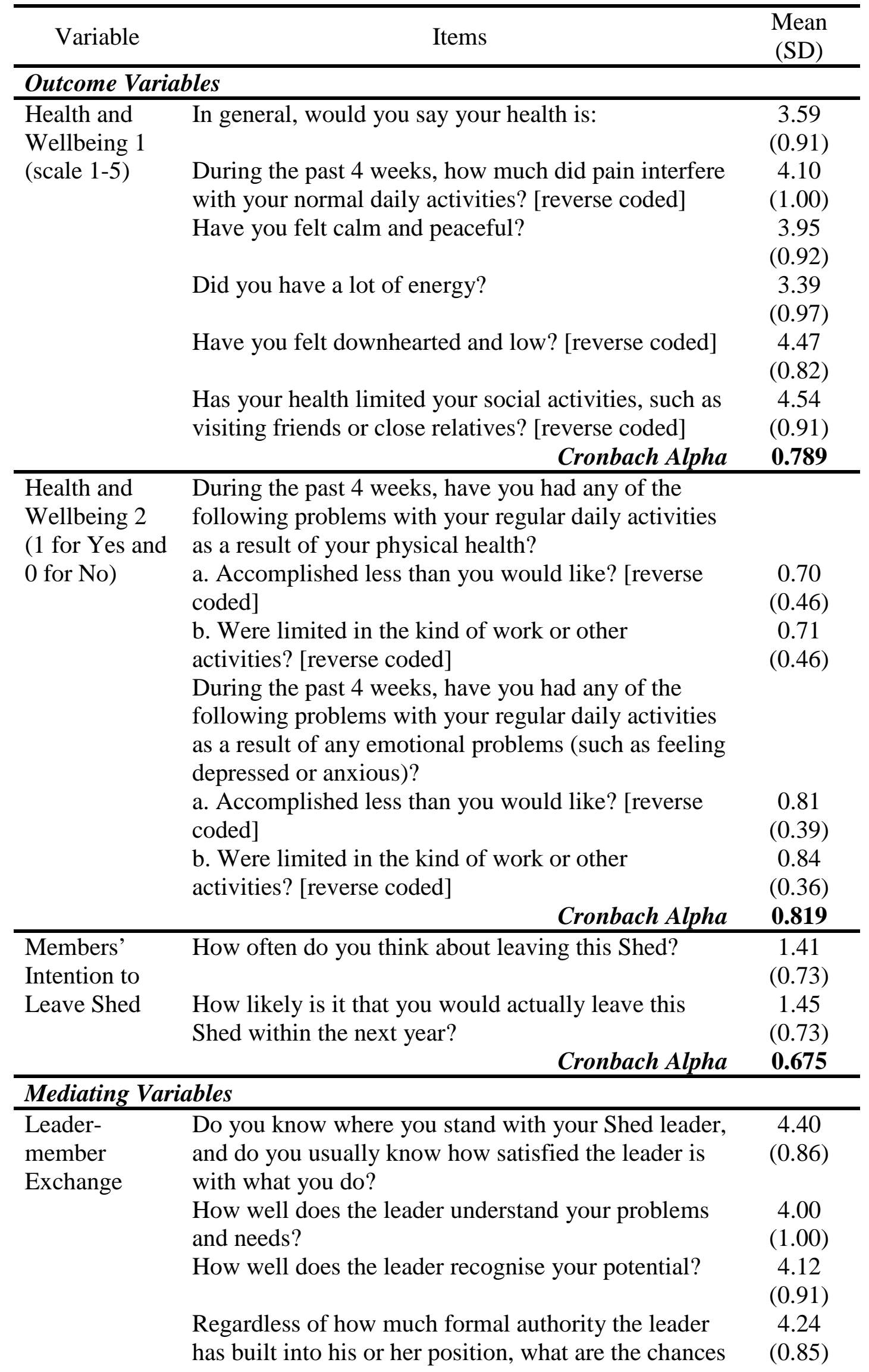


that the leader would use his or her power to help you solve problems in the Shed?

Again, regardless of the amount of formal authority the leader has, what are the chances that he or she

would "bail you out" at his or her expense?

I have enough confidence in the leader that I would

defend and justify his or her decision if he or she

were not present to do so.

How would you characterise your working

relationship with the leader? 
Table 3. Correlation Matrix ( $=419)$

\begin{tabular}{|c|c|c|c|c|c|c|c|c|c|c|c|c|c|c|c|c|}
\hline & Variable & Mean & S.D. & (1) & $(2)$ & (3) & (4) & (5) & (6) & (7) & (8) & (9) & $(10)$ & $(11)$ & $(12)$ & $(13)$ \\
\hline (1) & Health and wellbeing 1 & 0 & 1 & & & & & & & & & & & & & \\
\hline (2) & Health and wellbeing 2 & 0 & 1 & 0.70 & & & & & & & & & & & & \\
\hline (3) & Members' intention to leave & 0 & 1 & & - & & & & & & & & & & & \\
\hline (4) & $\begin{array}{l}\text { shed } \\
\text { Members’ perceived HR } \\
\text { practices }\end{array}$ & 0 & 2.56 & $\begin{array}{l}0.26 \\
0.07\end{array}$ & $\begin{array}{r}0.19 \\
- \\
0.00\end{array}$ & 0.29 & & & & & & & & & & \\
\hline (5) & Leader HR practices & 0 & 2.56 & 0.04 & 0.01 & $\begin{array}{r}- \\
0.05\end{array}$ & 0.18 & & & & & & & & & \\
\hline (6) & $\begin{array}{l}\text { Members' social } \\
\text { connectedness }\end{array}$ & 3.96 & 0.58 & 0.44 & 0.32 & $\begin{array}{r}- \\
0.31\end{array}$ & 0.33 & 0.04 & & & & & & & & \\
\hline (7) & Leader-member exchange & 0 & 1 & 0.12 & 0.04 & $\begin{array}{r}- \\
0.37\end{array}$ & 0.54 & 0.06 & 0.38 & & & & & & & \\
\hline (8) & Age & 69.32 & 8.34 & 0.07 & 0.01 & & $\begin{array}{r}- \\
0.03\end{array}$ & $\begin{array}{r}- \\
0.07\end{array}$ & 0.10 & 0.01 & & & & & & \\
\hline (9) & Attend other shed & 0.10 & 0.30 & 0.02 & $\begin{array}{r}- \\
0.07\end{array}$ & 0.10 & $\begin{array}{r}- \\
0.07\end{array}$ & 0.09 & 0.01 & $\begin{array}{r}- \\
0.07\end{array}$ & 0.06 & & & & & \\
\hline (10) & Attend training programs & 1.09 & 2.13 & 0.01 & 0.02 & $\begin{array}{r}- \\
0.06\end{array}$ & 0.24 & 0.04 & 0.13 & 0.11 & 0.01 & $\begin{array}{r}- \\
0.03\end{array}$ & & & & \\
\hline (11) & Health services used & 0.75 & 1.30 & 0.05 & 0.06 & 0.07 & 0.09 & 0.03 & 0.02 & 0.05 & 0.02 & 0.06 & 0.21 & & & \\
\hline (12) & Access to shed & 0.71 & 0.57 & 0.00 & 0.05 & $\begin{array}{r}- \\
0.06\end{array}$ & 0.07 & 0.18 & 0.08 & 0.10 & 0.03 & 0.02 & 0.10 & 0.07 & & \\
\hline (13) & Access to health services & 3.95 & $\begin{array}{r}12.9 \\
4\end{array}$ & 0.02 & 0.02 & 0.04 & 0.00 & 0.15 & 0.03 & 0.05 & 0.00 & 0.01 & 0.02 & 0.02 & 0.08 & \\
\hline (14) & Shed size & 50.12 & $\begin{array}{r}42.2 \\
1\end{array}$ & 0.04 & 0.04 & 0.00 & 0.20 & 0.24 & 0.01 & 0.02 & 0.07 & $\begin{array}{r}- \\
0.01\end{array}$ & 0.12 & 0.04 & 0.18 & 0.23 \\
\hline
\end{tabular}

$|\mathrm{r}|>0.085-p<0.10 ;|\mathrm{r}|>0.096-p<0.05 ;|\mathrm{r}|>0.126-p<0.01 ;|\mathrm{r}|>0.168-p<0.001$ 
Table 4. Linear Regression Results of Leader HR Practices and Members' Perceived HR Practices on Members' Social Connectedness and Leader-member Exchange

\begin{tabular}{|c|c|c|c|c|c|c|}
\hline & \multicolumn{2}{|c|}{$\begin{array}{c}\text { DV: } \\
\text { Members’ Perceived } \\
\text { HR Practices }\end{array}$} & \multicolumn{2}{|c|}{$\begin{array}{l}\text { DV: Members’ Social } \\
\text { Connectedness }\end{array}$} & \multicolumn{2}{|c|}{$\begin{array}{c}\text { DV: Leader-member } \\
\text { Exchange }\end{array}$} \\
\hline & Model 1 & Model 2 & Model 3 & Model 4 & Model 5 & Model 6 \\
\hline Intercept & $\begin{array}{r}-0.22 \\
(1.02)\end{array}$ & $\begin{array}{r}-0.43 \\
(1.01)\end{array}$ & $\begin{array}{l}3.39 * * * \\
(0.24)\end{array}$ & $\begin{array}{l}3.43 * * * \\
(0.23)\end{array}$ & $\begin{array}{r}-0.26 \\
(0.41)\end{array}$ & $\begin{array}{r}-0.17 \\
(0.35)\end{array}$ \\
\hline Age & $\begin{array}{r}-0.01 \\
(0.01)\end{array}$ & $\begin{array}{r}-0.01 \\
(0.01)\end{array}$ & $\begin{array}{c}0.01 * \\
(0.00)\end{array}$ & $\begin{array}{c}0.01 * \\
(0.00)\end{array}$ & $\begin{array}{r}0.00 \\
(0.01)\end{array}$ & $\begin{array}{r}0.00 \\
(0.00)\end{array}$ \\
\hline Attend other shed & $\begin{array}{r}-0.57 \\
(0.40)\end{array}$ & $\begin{array}{r}-0.47 \\
(0.40)\end{array}$ & $\begin{array}{l}-0.03 \\
(0.10)\end{array}$ & $\begin{array}{r}0.01 \\
(0.09)\end{array}$ & $\begin{array}{r}-0.21 \\
(0.16)\end{array}$ & $\begin{array}{r}-0.11 \\
(0.14)\end{array}$ \\
\hline $\begin{array}{l}\text { Attend training } \\
\text { programs }\end{array}$ & $\begin{array}{l}0.23 * * * \\
(0.06)\end{array}$ & $\begin{array}{l}0.23 * * * \\
(0.06)\end{array}$ & $\begin{array}{c}0.03 * \\
(0.01)\end{array}$ & $\begin{array}{r}0.02 \\
(0.01)\end{array}$ & $\begin{array}{c}0.05 * \\
(0.02)\end{array}$ & $\begin{array}{r}-0.00 \\
(0.02)\end{array}$ \\
\hline Health services used & $\begin{array}{r}0.07 \\
(0.09)\end{array}$ & $\begin{array}{r}0.06 \\
(0.09)\end{array}$ & $\begin{array}{r}-0.01 \\
(0.02)\end{array}$ & $\begin{array}{r}-0.01 \\
(0.02)\end{array}$ & $\begin{array}{r}0.02 \\
(0.04)\end{array}$ & $\begin{array}{r}0.01 \\
(0.03)\end{array}$ \\
\hline Access to shed & $\begin{array}{l}0.39 \dagger \\
(0.22)\end{array}$ & $\begin{array}{l}0.49 * \\
(0.22)\end{array}$ & $\begin{array}{r}0.06 \\
(0.05)\end{array}$ & $\begin{array}{r}0.02 \\
(0.05)\end{array}$ & $\begin{array}{l}0.18 * \\
(0.09)\end{array}$ & $\begin{array}{r}0.07 \\
(0.07)\end{array}$ \\
\hline $\begin{array}{l}\text { Access to health } \\
\text { services }\end{array}$ & $\begin{array}{r}-0.01 \\
(0.01)\end{array}$ & $\begin{array}{l}-0.01 \\
(0.01)\end{array}$ & $\begin{array}{r}0.00 \\
(0.00)\end{array}$ & $\begin{array}{r}0.00 \\
(0.00)\end{array}$ & $\begin{array}{r}0.00 \\
(0.00)\end{array}$ & $\begin{array}{c}0.01 \dagger \\
(0.00)\end{array}$ \\
\hline Shed size & $\begin{array}{l}0.01 * * * \\
(0.00)\end{array}$ & $\begin{array}{l}0.01 * * * \\
(0.00)\end{array}$ & $\begin{array}{r}-0.00 \\
(0.00)\end{array}$ & $\begin{array}{r}-0.00 \\
(0.00)\end{array}$ & $\begin{array}{r}-0.00 \\
(0.00)\end{array}$ & $\begin{array}{l}-0.00 * * \\
(0.00)\end{array}$ \\
\hline Leader HR practices & & $\begin{array}{l}0.15^{* *} \\
(0.05)\end{array}$ & $\begin{array}{r}-0.01 \\
(0.01)\end{array}$ & $\begin{array}{l}-0.02 \dagger \\
(0.01)\end{array}$ & $\begin{array}{r}0.03 \\
(0.02)\end{array}$ & $\begin{array}{l}-0.01 \\
(0.02)\end{array}$ \\
\hline $\begin{array}{l}\text { Members' perceived } \\
\text { HR practices }\end{array}$ & & & & $\begin{array}{l}0.08 * * * \\
(0.01)\end{array}$ & & $\begin{array}{l}0.22 \text { *** } \\
(0.02)\end{array}$ \\
\hline F-statistic & $6.57 * * *$ & $6.99 * * *$ & $1.74 \dagger$ & $7.32 * * *$ & $1.84 \dagger$ & $21.49 * * *$ \\
\hline $\begin{array}{l}\mathrm{R}^{2} \\
\Delta \mathrm{R}^{2}\end{array}$ & 0.101 & $\begin{array}{l}0.120 \\
8.83 * * *\end{array}$ & 0.033 & $\begin{array}{l}0.139 \\
50.29 * * *\end{array}$ & 0.035 & $\begin{array}{l}0.321 \\
171.85 * * *\end{array}$ \\
\hline Sobel Test (Z-score) & & & & $2.76 * *$ & & $2.92 * *$ \\
\hline
\end{tabular}

$\dagger p<0.10 ; * p<0.05 ; * * p<0.01 ; * * * p<0.001$ 
Table 5. Linear Regression Results of Members' Perceived HR Practices, Members' Social Connectedness and Leader-member Exchange on Members' Health and Wellbeing and Intention to Leave Shed

\begin{tabular}{|c|c|c|c|}
\hline & \multicolumn{2}{|c|}{ DV: Health DV: Health } & \multirow{3}{*}{$\begin{array}{l}\text { DV: } \\
\text { Intention to } \\
\text { Leave Shed }\end{array}$} \\
\hline & Wellbeing & Wellbeing & \\
\hline & 1 & 2 & \\
\hline & Model 1 & Model 2 & Model 3 \\
\hline \multirow[t]{2}{*}{ Intercept } & $-3.44 * * *$ & $-2.30 * * *$ & $1.55 * * *$ \\
\hline & $(0.47)$ & $(0.49)$ & $(0.47)$ \\
\hline \multirow[t]{2}{*}{ Age } & 0.00 & -0.01 & -0.01 \\
\hline & $(0.01)$ & $(0.01)$ & $(0.01)$ \\
\hline \multirow[t]{2}{*}{ Attend other shed } & -0.03 & -0.22 & 0.22 \\
\hline & $(0.15)$ & $(0.15)$ & $(0.15)$ \\
\hline \multirow{2}{*}{$\begin{array}{l}\text { Attend training } \\
\text { programs }\end{array}$} & -0.01 & -0.00 & 0.00 \\
\hline & $(0.02)$ & $(0.02)$ & $(0.02)$ \\
\hline \multirow[t]{2}{*}{ Health services used } & -0.04 & -0.05 & $0.07 *$ \\
\hline & $(0.03)$ & $(0.04)$ & $(0.03)$ \\
\hline \multirow[t]{2}{*}{ Access to shed } & -0.01 & 0.10 & -0.03 \\
\hline & $(0.08)$ & $(0.08)$ & $(0.08)$ \\
\hline \multirow{2}{*}{$\begin{array}{l}\text { Access to health } \\
\text { services }\end{array}$} & -0.00 & -0.00 & 0.00 \\
\hline & $(0.00)$ & $(0.00)$ & $(0.00)$ \\
\hline \multirow[t]{2}{*}{ Shed size } & 0.00 & $0.00 \dagger$ & 0.00 \\
\hline & $(0.00)$ & $(0.00)$ & $(0.00)$ \\
\hline \multirow[t]{2}{*}{ Leader HR practices } & 0.03 & 0.02 & -0.01 \\
\hline & $(0.02)$ & $(0.02)$ & $(0.02)$ \\
\hline \multirow{6}{*}{$\begin{array}{l}\text { Members' perceiv } \\
\text { HR practices } \\
\text { Members' social } \\
\text { connectedness } \\
\text { Leader-member } \\
\text { exchange }\end{array}$} & $-0.04 \dagger$ & $-0.05 *$ & $-0.04 \dagger$ \\
\hline & $(0.02)$ & $(0.02)$ & $(0.02)$ \\
\hline & $0.82 * * *$ & $0.66 * * *$ & $-0.30 * * *$ \\
\hline & $(0.08)$ & $(0.09)$ & $(0.08)$ \\
\hline & -0.01 & -0.03 & $-0.25 * * *$ \\
\hline & $(0.05)$ & $(0.06)$ & $(0.05)$ \\
\hline Chi-square & $113.33 * * *$ & $67.99 * * *$ & $101.96 * * *$ \\
\hline $\mathrm{R}^{2}$ & 0.213 & 0.140 & 0.196 \\
\hline \multicolumn{4}{|l|}{$\Delta \mathrm{R}^{2}$} \\
\hline \multicolumn{4}{|c|}{ Seemingly Unrelated Regression Test (Z-score) } \\
\hline $\begin{array}{l}\text { Via Members' social } \\
\text { connectedness }\end{array}$ & $5.82 * * *$ & $5.22 * * *$ & $-3.19 * * *$ \\
\hline $\begin{array}{l}\text { Via Leader-member } \\
\text { exchange }\end{array}$ & -0.10 & -0.56 & $-4.28 * * *$ \\
\hline Overall mediation & $4.20 * * *$ & $3.07 * *$ & $-5.75 * * *$ \\
\hline
\end{tabular}

$\dagger p<0.10 ; * p<0.05 ; * * p<0.01 ; * * * p<0.001$ 


\section{References}

Alfes, K., Shantz, A., \& Truss, C. (2012). The link between perceived HRM practices, performance and well-being: the moderating effect of trust in the employer. Human Resource Management Journal, 22(2), 409-427.

Alfes, K., Shantz, A. D., Truss, C., \& Soane, E. C. (2013). The link between perceived human resource management practices, engagement and employee behaviour: a moderated mediation model. The International Journal of Human Resource Management, 24(2), 330-351.

Almedom, A. M. (2005). Social capital and mental health: An interdisciplinary review of primary evidence. Social Science \& Medicine, 61, 943-964.

Alreck, P. L., \& Settle, R. P. (1995). The Survey Research Handbook. New York: Irwin.

Arney, F., \& Westby, M. (2012). Mens places literature reveiw. Darwin, NT: Child Protection Research Program, Menzies School of Health Research.

Australian Bureau of Statistics. (2011). Australian Social Trends. Canberra: Australian Bureau of Statistics

Australian Men's Shed Association. (2013). Australian Men's Shed Association Retrieved 22 March, 2013, from http://www.mensshed.org

Ballinger, M., Talbot, L., \& Verrinder, G. (2009). More than a place to do woodwork: A case study of a community-based men's shed. Journal of Men's Health, 6(1), 20-27.

Baron, R. M., \& Kenny, D. A. (1986). The moderator-mediator variable distinction on social psychological research: Conceptual, strategic, and statistical considerations. Journal of Personality and Social Psychology, 51, 1173-1182.

Bartram, T., \& Casimir, G. (2007). The relationship between leadership and follower in-role performance and satisfaction with the leader. Leadership and Organizational Development Journal, 28(1), 4-19.

Bartram, T., Karimi, L., Leggat, S., \& Stanton, P. (2014). Social identification: linking high performance work systems, psychological empowerment and patient care. International Journal of Human Resource Management, (in press).

Baumeister, R. F., \& Leary, M. R. (1995). The need to belong: Desire for interpersonal attachment as a fundamental human motivation. Psychological Bulletin, 117, 497529.

Blau, P. (1964). Exchange and Power in Social Life. New York: Wiley.

Bonias, D., Bartram, T., Leggat, S. G., \& Stanton, P. (2010). Does psychological empowerment mediate the relationship between high performance work systems and patient care quality in hospitals? . Asia Pacific Journal of Human Resources, 48(3), 319-337.

Bowen, D. E., \& Ostroff, C. (2004). Understanding HRM-firm performance linkages: The role of the strength of the HRM system. The Academy of Management Review, 29(2), 203-221

Boxall, P., Ang, S. H., \& Bartram, T. (2011). Studying HR strategy in context: Mapping a HR system for casual workers in a cinema chain. Forthcoming in the Journal of Management Studies.

Boxall, P., \& Macky, K. (2007). High-performance work systems and organisational performance: Bridging theory and practice. Asia Pacific Journal of Human Resources, 45(3), 261-270.

Brown, M., Golding, B., \& Foley, A. (2008). Out the back: Mens sheds and informal learning. Fine Print, 31(2), 12-15.

Butterworth, P., Gill, S. C., Rodgers, B., Anstey, K. J., Villamil, E., \& David Melzer, D. (2006). Retirement and mental health: Analysis of the Australian national survey of mental health and well-being. Social Science and Medicine, 62. 
Cavanagh, J., McNeil, N., \& Bartram, T. (2012). The Australian mens shed movement: Human resource management in a voluntary organisation Asia Pacific Journal of Human Resources, 51(3), 292-306.

Cavanagh, J., McNeil, N., \& Bartram, T. (2013). The Australian men's shed movement: Human resource management in a voluntary organisation. Asia Pacific Journal of Human Resources, 51(3), 292-306.

Cavanagh, J., McNeil, N., Bartram, T., \& Leggat, S. (2012). An exploratory study of the factors that promote Indigenous and non-Indigenous member's participation in Men's Sheds. Journal of Australian Indigenous Issues, 15(1), 50-64.

Chavis, D. M., \& Wandersman, A. (1990). Sense of community in the urban ennvironment: A catalyst for participation and community development. American Journal of Community Psychology, 18, 55-81.

Cornwell, B., \& Edward, O. L. (2013). The health benefits of network growth: new evidence from a national survey of older adults. Social Science and Medicine.

Cornwell, B., Laumann, E. O., Philip, L., \& Schumm, P. (2008). The social connectedness of older adults: a national profile. American Sociological Review, 73(2), 185-203.

Edgar, F., \& Geare, A. (2005). HRM practice and employee attitudes: Different measures different results. Personnel Review, 34(5), 534-549.

Forrester, W. R., \& Tashchian, A. (2006). Modeling the Relationship between Cohesion and Performance in Student Workgroups. International Journal of Management, 23(3), 458-464.

Glover, C., \& Brown, E. (2006). Written feedback for students: Too much, too detailed or too incomprehensible to be effective? Bioscience education e-journal, 7, 7-22.

Golding, B. (2011). Social, local, and situated: Recent findings about the effectiveness of older mens informal learning in community contexts. Adult Education Quarterly, 61(2), 103-120.

Golding, B., Brown, M., Foley, A., Harvey, J., \& Gleeson, L. (2007). Mens sheds in Australia: Learning through community contexts. In A National Vocational Education and Training Research and Evaluation Program Report (Ed.). Adelaide, Australia: National Centre for Vocational Education Research (NCVER).

Golding, B., Kimberley, H., Foley, A., \& Brown, M. (2008). Houses and sheds in Australia: an exploration of the genesis and growth of neighbourhood houses and mens sheds in community settings. Australian Journal of Adult Learning, 48(2), 237-262.

Golub, S. A., Filipowicz, A., \& Langer, E. J. (2002). Acting your age. In T. D. Nelson (Ed.), Ageism: Stereotyping and prejudice against older persons (pp. 277-294). Cambridge, MA: MIT Press.

Gould-Williams, J. (2007). HR practices, organizational climate and employee outcomes: evaluation social exchange relationships in local government. International Journal of Human Resource Management, 18(9), 1627-1647.

Graen, G. B., \& Uhl-Bien, M. (1995). Relationship-based approach to leadership: Development of leader-member exchange (LMX) theory of leadership over 25 years: Applying a multi-level multi-domain perspective. Leadership Quarterly, 6(2), 219247.

Grant, A. M., Christianson, M. K., \& Price, R. H. (2007). Happiness, health, or relationships? Managerial practices and employee well-being tradeoffs. Academy of Management Perspectives., 21(3), 51-63.

Guest, D. (2002). Human resource management, corporate performance and employee wellbeing: Building the worker into HRM. Journal of Industrial Relations, 44(3), 335-358. 
Gundlach, M., Zivnuska, S., \& Stoner, J. (2006). Understanding the relationship between individualism-collectivism and team performance through integration of social identity theory and the social relations model. Human Relations, 59(12), 1603-1632.

Hayes, A. F. (2009). Beyond Baron and Kenny: Statistical mediation analysis in the new millennium. Communication Monographs, 76, 408-420.

Jacques, P. H., Garger, J., Thomas, M., \& Vracheva, V. (2012). Effects of early LeaderMember Exchange perceptions on academic outcomes. Learning Environment Research, 15, 1-15.

Kramar, R., Bartram, T., \& DeCieri, H. (2014). Human Resource Management: Strategy, People, Performance (4th ed.). Sydney: McGraw-Hill.

Kuvaas, B. (2008). An exploration of how the employee-organization relationship affects the linkage between perception of developmental human resource practices and employee outcomes. Journal of Management Studies, 45(1), 1-25.

Kuvaas, B., \& Dysvik, A. (2010). Exploring alternative relationships between perceived investment in employee development, perceived supervisor support and employee outcomes. Human Resource Management Journal, 20(2), 138-156.

Labonte, R., \& Reid, E. (1997). Participation and Partnerships for Health Promotion. Carlton: Victoria Health.

Lam, W., Chen, Z., \& Takeuchi, N. (2009). Perceived human resource management practices and intention to leave of employees: the mediating role of organizational citizenship behaviour in a Sino-Japanese joint venture. The International Journal of Human Resource Management, 20(11), 2250-2270.

Lee, R. M., Draper, M., \& Lee, S. (2001). Social connectedness, dysfunctional interpersonal behaviors, and psychological distress: Testing a mediator model. Journal of Counseling Psychology, 48(3), 310-318.

Lee, R. M., Keough, K. A., \& Sexton, J. D. (2002). Social connectedness, social appraisal, and perceived stress in college women and men. Journal of Counseling and Development, 80, 355-361.

Lee, R. M., \& Robbins, S. B. (2000). Understanding social connectedness in college women and men. Journal of Counseling and Development, 78, 484-491.

Li, X., K, S., \& Frenkel, S. (2012). How leader-member exchange, work engagement and HRM consistency explain Chinese luxury hotel employees' job performance. International Journal of Hospitality Management, 31, 1059-1066.

Liao, H., Toya, K., Lepak, D. P., \& Hong, Y. (2006). Do they see eye to eye? Management and employee perspectives of high-performance work systems and influence processes on service quality. Journal of Applied Psychology, 94(2), 371-391.

Marshall, V. P., Clarke, P., \& Ballantyne, P. (2001). Instability in the retirement transition: Effects on health and wellbeing in a Canadian study. Instability in the retirement transition: Effects on health and wellbeing in a Canadian study, Research on Aging(23), 379-409.

Masterson, M. S., Lewis, K., Goldman, B. M., \& Taylor, M. S. (2000). Integrating justice and social exchange: The differing effects of fair procedures and treatment on work relations. Academy of Management Journal, 43(4), 738-748.

McKinnon, D. P., Krull, J. L., \& Lockwood, C. M. (2000). Equivalence of the mediation, confounding, and suppression effect. Prevention Science, 1, 173-181.

Mensheds Australia. (2013). Mensheds Australia Retrieved October 30, 2013, from www.mensheds.org.au

Misan, G. (2008). Men's Sheds - a strategy to improve men's health: Spencer Gulf Rural Health School (SGRHS), The University of Adelaide and the University of South 
Australia and Centre for Rural Health and Community Development (CRHaCD), University of South Australia.

Mobley, W. H., Horner, S. O., \& Hollingsworth, A. T. (1978). An evaluation of precursors of hospital employee turnover. Journal of Applied Psychology, 63(4), 408-414.

Morgan, M., Hayes, R., Williamson, M., \& Ford, C. (2007). Men's Sheds: A community approach to promoting mental health and well-being. International Journal of Mental Health Promotion, 9(3), 48-52.

Nelson, D., Basu, R., \& Purdie, R. (1998). An Examination of Exchange Quality and Work Stressors in Leader-Follower Dyads. International Journal of Stress Management, 5(2), 103-112.

Ormsby, J., Stanley, S, Jaworski, K. (2010). Older men's participation in community-based men's sheds programmes. Health and Social Care in the Community, 18(6), 607-613.

Pfefer, J. (1998). The human equation: building profits by putting people first. Boston: Harvard Business School Press.

Postmes, T. (2003). A social identity approach to communication in organisations Social identity at work: Developing theory for organisational practice (pp. 81-98). Philadelphia, PA: Psychology Press.

Preacher, K. J., \& Hayes, A. F. (2008). Asymptotic and resampling strategies for assessing and comparing indirect effects in multiple mediator models. Behavioral Research Methods, 40, 879-891.

Pretty, G. M. H., Conroy, C., Dugay, J., Fowler, K., \& Williams, D. (1996). Sense of community and its relevance to adolescents of all ages. Journal of Community Psychology, 24(4), 365-379.

Purcell, J., \& Hutchinson, S. (2007). Front-line managers as agents in the HRM performance causal chain: theory, analysis and evidence. Human Resource Management Journal, 17(1), 3-20.

Rousseau, V., Aubé, C., Chiocchio, F., Boudrias, J., \& Morin, E. M. (2008). Social Interactions at Work and Psychological Health: The Role of Leader-Member Exchange and Work Group Integration. Journal of Applied Social Psychology, 38(7), $1755-1777$.

Schuler, R. S., \& Jackson, S. E. (1987). Linking competitive strategy with human resource management practices Academy of Management Executive, 3, 207-219.

Shrout, P. E., \& Bolger, N. (2002). Mediation in experimental and nonexperimental studies: New procedures and recommendations. Psychological Methods, 7, 422-445.

Singh, A., \& Misra, N. (2009). Loneliness, depression and sociability in old age. Industrial Psychiatry Journal, 18(1), 51-55.

Sirven, N., \& Debrand, T. (2008). Social participation and healthy ageing: An international comparison using SHARE dataq. Social Science and Medicine, 67, 2017-2026.

Sirven, N., \& Debrand, T. (2012). Social capital and health of older Europeans: Causal pathways and health inequalities. Social Science and Medicine, 75(7), 1288-1295.

Southcombe, A., Cavanagh, J., \& Bartram, T. (2013 In press). Capacity Building in Indigenous Men's Groups and Sheds across Australia. Health Promotion International.

Stanton, P., Young, S., Bartram, T., \& Leggat, S. G. (2010). Singing the same song: translating HRM messages across management hierarchies in Australian hospitals The International Journal of Human Resource Management, 21(4), 567-581.

Stryker, S., \& Serpe, R. T. (1994). Identity salience and psychological centrality: Equivalent, overlapping, or complementary concepts? Social Psychology Quarterly, 57(1), 16-35.

Thomas, G., Martin, R., \& Riggio, R. E. (2013). Leading groups: Leadership as a group process. Group Processes and Intergroup Relations, 16(1), 3-16. 
Townsend, K. C., \& McWhirter, B. T. (2005). Connectedness: A review of the literature with implications for counseling, assessment and research. Journal of Couseling and Development, 83(2), 191-201.

Van De Voorde, K., Paauwe, J., \& Van Veldhoven, M. (2011). EmployeeWell-being and the HRM-Organizational Performance Relationship: A Review of Quantitative Studies. International Journal of Management Reviews, 14, 391-407.

Warburton, J., \& Lui, C. (2007). Social isolation and loneliness in older people: a literature review. In Report for the Office for Seniors Queensland Department of Communities Australasian Centre on Ageing (Ed.). St Lucia: University of Queensland.

Whitlock, J. (2007). The role of adults, public space, and power in adolescent community connectedness. Journal of Community Psychology, 35(4), 499-518.

Wood, R. E., Goodman, J. S., Beckmann, N., \& Cook, A. (2008). Mediation testing in management research - A review and proposals. Organizational Research Methods, 11, 270-295.

Zacharatos, A., Barling, J., \& Iverson, R. D. (2005). High-performance work systems and occupational safety. Journal of Applied Psychology, 90(1), 77-93.

Zhu, W., Sosik, J. J., Riggio, R. E., \& Yang, B. (2012). Relationships between transformational and active transactional leadership and followers organizational identification: the role of psychological empowerment. Retrieved from 